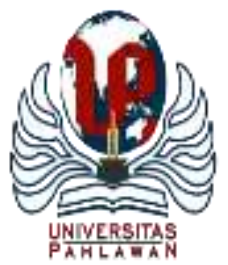

Edukatif : Jurnal Ilmu Pendidikan Volume 3 Nomor 6 Tahun 2021 Halm 4750 - 4756

EDUKATIF: JURNAL ILMU PENDIDIKAN

Research \& Learning in Education

https://edukatif.org/index.php/edukatif/index

\title{
Manajemen Pondok Pesantren dalam Pengembangan Mutu Pendidikan Islam di Pondok Pesantren Pangeran Diponegoro Sleman
}

\author{
Erhat Zakiyatul Aini \\ UIN Sunan Kalijaga Yogyakarta, Indonesia \\ E-mail : erhatzakiyya@gmail.com
}

\begin{abstract}
Abstrak
Mutu menjadi tolak ukur dalam melihat segala sesuatu bagi konsumen atau peminat, termasuk dalam pendidikan. pendidikan harus mempunyai mutu yang baik untuk dapat terus bertahan. Dalam pendidikan mengharuskan untuk terus meningkatkan mutu dengan berkembangnya kemajuan teknologi dan informasi, dan perubahan zaman menjadikan pendidikan dalam menghadapi persaingan agar terus berinovasi dengan kemajuan era teknologi, dan sistem yang dibutuhkan oleh masyarakat, termasuk dalam hal ini adalah pesantren sebagai lembaga pendidikan Islam dimana perkembangan zaman ini juga harus diiringi dengan moral yang kuat, sehingga peran pendidikan Pondok Pesantren juga penting. Penelitian ini bertujuan untuk mengetahui bagaimana Pondok pesantren Pangeran Diponegoro ini berusaha meningkatkan mutu pendidikanya. Penelitian ini menggunakan jenis penelitian kualitatif yaitu penelitian pengamatan dan wawancara secara mendalam dengan pihak terkait, juga menggunakan analisis deskriptif sebagai alat untuk menggali data yang lebih dalam tentang informasi berkaitan dengan Ponpes Pangeran Diponegoro dengan merumuskan masalah dengan lebih rinci. hasil penelitian bahwa manajemen perencanaan mutu pendidikan yang dijalankan oleh Ponpes Pangeran Diponegoro dengan memenuhi syarat-syarat pendidikan pesantren bermutu dengan keunggulan memadukan kurikulum pendidikan umum dan kurikulum pesantren dalam pendidikan formal
\end{abstract}

Kata Kunci: Manajemen mutu, pendidikan, pesantren.

\begin{abstract}
Quality is a benchmark in seeing everything for consumers or enthusiasts, including in education. Education must be of good quality in order to survive. In education, it is necessary to continue to improve quality with the development of advances in technology and information, and the times make education in the face of competition so that it continues to change along with the advancement of the technological era, and the system needed by the community, including in this case the Islamic boarding school as an Islamic educational institution where the development of this era must also be accompanied by strong morals, so the role of Islamic boarding school education is also important. This study aims to find out how the Pangeran Diponegoro Islamic Boarding School is trying to improve the quality of its education. This study uses qualitative research, namely research and in-depth interviews with related parties, also uses descriptive analysis as a tool to find deeper data with other parties. the results of the study that the management of education quality planning carried out by the Pangeran Diponegoro Islamic Boarding School by fulfilling the requirements of quality Pesantren education with the advantage of combining the general education curriculum and educators.
\end{abstract}

Keywords: Quality manajemen, education, pesantren.

Copyright (c) 2021 Erhat Zakiyatul Aini

$\triangle$ Corresponding author

Email : erhatzakiyya@gmail.com

DOI : https://doi.org/10.31004/edukatif.v3i6.1543

ISSN 2656-8063 (Media Cetak)

ISSN 2656-8071 (Media Online)

Edukatif : Jurnal Ilmu Pendidikan Vol 3 No 6 Tahun 2021 p-ISSN 2656-8063 e-ISSN 2656-8071 
4751 Manajemen Pondok Pesantren dalam Pengembangan Mutu Pendidikan Islam di Pondok Pesantren Pangeran Diponegoro Sleman - Erhat Zakiyatul Aini

DOI: https://doi.org/10.31004/edukatif.v3i6.1543

\section{PENDAHULUAN}

Mencerdaskan kehidupan bangsa merupakan cita-cita Indonesia yang terekam dalam UUD 1945. Tujuan mulia tersebut sebagai dasar untuk membentuk pendidikan yang baik. Dari cita-cita mulia tersebutlah sebagai dukungan untuk untuk didirikan lembaga-lembaga pendidikan yang kedepannya memberikan kesempatan anak bangsa merasakan pendidikan yang layak, baik bersifat normal maupun nonformal. Dalam sejarahnya pendidikan formal merupakan pendidikan dengan sistem yang berasal dari penjajah seperti belanda dan jepang seperti SD, SMP, dan SMA. (Madjid 2010) Sedang pendidikan nonformal yaitu pendidikan yang dihasilkan dari para pendatang yang berdagang yang rata-rata berasal dari negeri Islam seperti India, Gujarat ataupun negeri Timur Tengah yang menyebarkan Islam di daerah-daerah pantai, yang sampai sekarang pendidikan ini dikenal salah satunya berupa Pondok Pesantren (Suwadji 2014). Pondok Pesantren yang selanjutnya akan disebut Ponpes merupakan sebuah pendidikan yang dikembangkan masyarakat sebagai wujud penyesuaian budaya yang terdapat di daerah tersebut, bentuk pendidikan inilah kemudian dinamakan pendidikan non formal karena dibentuk dari budaya masyarakat dan dikembangkan sesuai kultur masyarakat tersebut (Syaiful 2016). Ponpes ini mengajarkan ilmu-ilmu agama dan sangat berkembang di pulau Jawa sejak aman penjajahan (Basyir 2007). Namun mulai berkembangnya zaman pendidikan ini kurang diminati karena kurang berkembang dalam hal sistem pendidikanya, sehingga pendidikan ini semakin sedikit peminatnya dan bergeser ke daerah pedesaan.

Dari persoalan sistem pendidikan Ponpes yang kurang berkembang, padahal untuk materi dan tujuan dari Ponpes sebagai pendidikan agama sangat berperan penting dalam tujuan pendidikan. Dikeluarkanlah UU No. 20 Tahun 2003 tentang (SISDIKNAS). Dalam UU tersebut Ponpes yang sebelumnya hanya mengajarkan tentang pembelajaran agama dan berkaitan dengan moral, berganti menjadi sebuah lembaga pendidikan keagamaan yang diberi wewenang untuk mendirikan pendidikan formal berupa sekolah atau madrasah, (Pendidikan 2003) yang menggunakan sistem pendidikan lebih modern dan memadukan pendidikan formal dan pendidikan non-formal. Hingga saat ini sangat sedikit pesantren dengan sistem pendidikan tradisional, dengan kata lain kurikulum lembaga pendidikan Ponpes tidak hanya mengenai persoalan keagamaan namun juga kurikulum yang menyentuh dengan perkembangan zaman (El-sha, HS. Matsuki dan Ishom 2006).

Ponpes akhirnya dapat bersaing dengan sistem pendidikan formal dan dapat lebih modern dengan inovasi-inovasi yang berkaitan dengan persaingan produk yang dibutuhkan masyarakat. Ponpes mulai membuka diri dengan perbaikan mutu pendidikan (Ahmad 2013). Respon Ponpes sebagai sebuah lembaga pendidikan keagamaan dari peningkatan mutu dan perkembangan zaman dengan perubahan sosial masyarakat mencakup 4 hal, yaitu; isi atau kurukulum Ponpes dengan memasukan pendidikan umum. Kedua, pembaharuan dari metode pendidikan seperti perjenjangan, ketiga tentang sistem kelembagaan, keempat tentang fungsi pendidikan yang berkembang lebih kepada fungsi sosial. Dengan berkembangnya Ponpes seperti ini menjadikan Ponpes sebagai lembaga yang mulai banyak diminati dari berbagai kalangan. Ponpes tetap menjaga nilai dan tradisi ke pondok pesantrenan yang mengedepankan moral dan iman namun juga beradaptasi dengan pola baru yang dpat mendukung tetap berjalannya sistem Ponpes itu sendiri (Siswanto 2015).

Dari penjelasan diatas,Pondok Pesanren Pangeran Diponegoro, Sambego, Maguwoharjo Depok Sleman Yogyakarta, menyatakan bahwa perkembangan Ponpes semakin baik seperti memperluas jenis-jenis pendidikan yang diperlukan sesuai dengan perkembangan masyarakat saat ini. Sehingga hal tersebut terhindar dari pada kesenjangan antara sistem pendidikan Islam dengan ajaran Islam, dikarenakan ajaran Islam itu sendiri sangat mengedepankan terhadap keseimbangan dunia dan akhirat (Hartono 2017). Sehingga sebagai sebuah lembaga pendidikan Islam yang bersifat keagamaan. Pondok Pesanren Pangeran Diponegoro, yang terletak di Saembego, Maguwoharjo Depok Sleman Yogyakarta, mampu menyandingkan antara pendidikan keagamaan dan pelajaran umum. Maka berbagai faktor akan terus diupayakanuntuk mencapai tujuan seperti : 
berupa peningkatan sistem pendidikan yang terus berinovasi seperti pembaharuan kurikulum, peningkatan sarana dan prasarana pendidikan, metode dan strategi untuk meningkatkan mutu pendidikan serta manajemen yang lebih baik (Feiby 2018). Demikian beberapa faktor yang menjadi dasar dari penelitian ini, untuk mngetahui lebih dalam tentang manajemen mutu Pondok Pesantren Pangeran Diponegoro.

\section{METODE PENELITIAN}

Penelitian ini menggunakan jenis penelitian kualitatif yang berakar pada latar belakang yang alamiah atau penulis sama sekali tidak mempengaruhi. Data yang ditulis merupakan data yang sesuai dengan fakta yang ditemukan dilapangan. Penelitian ini sangat berkaitan dengan manusia, yaitu wawancara-wawancara dengan responden yang berkaitan dalam hal ini adalah pihak Yayasan atau pengurus dari Ponpes dan juga para pengajar lembaga pendidikan formal Yayasan Pangeran Diponegoro. Penelitian ini juga menggunakan analisis data secara induktif yang mengarahkan responden untuk menemukan teori dari dasar (Moleong 2018).

Penelitian ini bersifat deskriptif yang berupa penjabaran-penjabaran data yang dihasilkan dari wawancara, observasi, juga dokumentasi berupa dokumen yang berkaitan dengan penelitian. Menggunakan jenis evaluasi deskriptif sebagai kegiatan pengumpulan data yang mengungkapkan gambaran dari suatu teori atau konsep juga menjawab berbagai pertanyaan yang berkaitan dengan status dari responden atau subjek penelitian pada saat pengambilan data, misalnya sikap personal atau pendapat perseorangan yang berkaitan dengan kelembagaan dan yang lain-lain (Mulyadi 2011). Lokasi penelitian ini terdapat di Ponpes Diponegoro, Maguwo, Sleman, waktu penelitian ini dilakukan hanya sekitar 2 minggu terhitung dari tanggal 11 Februari sampai 26 Februari 2020. Subjek penelitian ini adalah para pengurus, pengajar, serta pegawai yang berada pada Yayasan Ponpes Diponegoro Maguwo Sleman. Tujuan dari penelitian ini tidak lain adalah untuk mengungkapkan informasi atau data berkaitan dengan perkembangan Ponpes Pangeran Diponegoro dalam meningkatkan mutu lembaga pendidikan.

Penelitian ini merupakan penelitian evaluasi yang merupakan penelitian yang lebih menekankan pengumpulan data untuk di deskripsikan kepada keadaan lapangan yang sesungguhnya (Dwi Muryadi 2017). Penelitian pendekatan kualitatif ini didasarkan pada pertimbangan yang mendasarkan gejala dalam penelitian ini merupakan proses pengumpulan data sebagaimana pandangan masyarakat tentang pendidikan yang terdapat di naungan Ponpes. Dari penelitian inilah peneliti berharap wawasan-wawasan dari pihak masyarakat umum dan pihak yang berkepentingan (stekholder) dapat terbuka dan tidak memandang Ponpes sebagai sebuah lembaga pendidikan yang dibawah standar dan tidak dapat bersaing dengan lembaga umum lainya.

\section{HASIL DAN PEMBAHASAN PENELITIAN}

Manajemen mutu pendidikan adalah bagaimana proses pengelolaan atau manajemen dilakukan secara konsisten atau terus menerus yang berdasar pada standar yang sudah ditentukan (Masyhud 2003). Dalam hal ini jika dikaitkan dengan Ponpes atau manajemen mutu pendidikan berbasis pesantren berarti peningkatan kualitas pendidikan tersebut berorientasi pada nilai-nilai keagamaan atau nilai ke-Islaman (kepesantrenan), yang telah menjadi budaya pada bangsa Indonesia. Mutu juga fokus terhadap kepuasan stakeholder, dengan ini untuk digunakan alat, metode, atau strategi untuk menciptakan budaya mutu tersebut. manajemen mutu yang berbasis pesantren juga selalu mengedepankan sinergi fungsi-fungsi manajemen, dalam hal ini produktivitas juga yang menyertainya berupa konsep mutu dan kerja tim serta kepuasan dari stakeholder yang menghasilkan lembaga dikelola secara efektif dan juga efisien. Menurut Baharrudin dan Makin Sebuah lembaga pendidikan berbasis pesantren dapat dikatakan bermutu apabilamemenuhi syarat-syarat berikut(Makin 2010): 
1) Ponpes berusaha untuk mengembangkan dan memperbaiki kurikulum yang dapat memenuhi tuntutan yang sistemik seperti kurikulum dari Kemnedikbud atau Kemenag, juga tuntutan sosial (stakeholder) dengan tetap mengedepankan pendekatan prinsip kepesantrenan (Makin 2010). Ponpes Pangeran Diponegoro seperti yang telah dijelaskan, pendirian pesantren ini sebelumnya merupakan sekolah berbasis Islam yaitu Madrasah Ibtidaiyah dan kemudian disusul SMP dan SMK. Pendirian pesantren merupakan sebuah usaha untuk lebih melestarikan prinsip Islam, dan nyatanya hingga sekarang upaya pengembangan dengan pendirian pesantren dapat dilihat keberhasilanya, SMP Diponegoro hingga saat ini masih berdiri bahkan berkembang, memiliki 3 kelas perjenjangnya, dan dalam pembangunan untuk fasilitas gedungnya, tidak hanya itu yayasan Diponegoro juga telah mendirikan SMK, yang cukup diminati oleh masyarakat daerah Maguwoharjo. Dapat dikatakan bahwa Ponpes Diponegoro ini terus mengembahkan dan memperbaiki kurikulum dengan menggabungkan dengan Ponpes dan mengikuti tuntutan sistemik dengan pendirian SMK dan SMP sebagai sekolah formal. Meskipun awal pendirian adalah MI kemudian baru dibentuk pesantren setelah berhasil dengan konsep pesantren itulah mulai berkembang untuk mendirikan lembaga formal lainya (Fatoni 2019).

Berdasarkan penjelasan diatas dapat ditemukan bahwa pengembangan manajemen Ponpes Pangeran Diponegoro merupakan Sebuah lembaga pendidikan yang menggabungkan kurikulum pendidikan formal dengan kurikulum pendidikan nonformal. Dengan kegiatan kepesantrenan yang dilakukan dengan mondok. Dengan perpaduan pendidikan umum (DEPDIKNAS) berbasis sekolah bukan berbasis Madrasah yang menjadi daya Tarik sendiri untuk masyarakat sekitar. Dalam pelaksanaan programpembelajaran di Ponpes Diponegoro memadukan antara pelajaran-pelajaran danpelajaran pesantren, seperti diketahui para santri yang mondok di pesantren Diponegoro wajib sekolah di sekolah yang tersedia di yayasan pesantren, jadi santri mendapatkan pelajaran yang lengkap.

Sekolah yang tergabung dalam yayasan pesantren ini tetap bertahan bahkan mengalami perkembangan yang tidak kalah dengan sekolah umum lainnya, Salah satunya adalah sekolah-sekolah tersebut berbasis pesantren, dan tidak mengesampingkan pendidikan umum, adanya perpaduan pendidikan umum dan agama inilah yang membuat sekolah ini mampu bersaing diantara sekolah-sekolah yang berada di Sleman khususunya daerah Maguwoharjo. SMP dan SMK adalah jenis sekolah umum bukan Madrasah tidak seperti pada sekolah pesantren lainnya yang bernaung di Kemenag (kementerian Agama), kendati begitu, kurikulum agama yang terdapat pada SMP dan SMK tersebut sama dengan Madrasah. Di dalamnya terdapat mata pelajaran agama Islam secara spesifik seperti pelajaran Fiqh, Aqidah Akhlak, SKI (sejarah kebudayaan Islam), bahkan beberapa pembalejaran mata pelajaran tersebut menggunakan kitab kuning (kitab klasik) dalam pembelajarannya

Beberapa hal yang tak kalah menarik adalah bagaimana manajemen di Ponpes Pangeran Diponegoro ini yaitu perpaduan antara kurikulum umum pendidikan Nasional dan Kurikulum Pesantren memacu kreatifitas serta prestasi dari siswa-siswa di Sekolah yang tergabung pada Ponpes Pangeran Diponegoro dalam berbagai kompetisis baik tingkat sekolah maupun di luar sekolah. Seperti perlombaan pembacaan kitab kuning yang diadakan setiap tahun, lomba POSPEDA (pekan olahraga santri daerah) antar pondok pesanten dan prestasi di bidang olahraga Voli yang mencapai tingkat nasional.

2) Semua lembaga dibawah Yayasan Ponpes Pangeran Diponegoro berakreditasi (A). kegiatan ekstrakurikulernya pun menarik dan beragam antara lain; Kelas pembinaan Tahfidz Al-Qur'an, Marawis, Kitab Kuning, Pidato, Pembelajaran komputer, Bahasa asing, kaligrafi, silat, juga ada kegiatan ekstrakulikuler yang umum seperti pramuka, marching band, jurnalistik dan pengembangan Exacta (Lab skill) dan olahraga basket, sepak bola, dan Voli yang sesuai dengan kepesantrenan. Dari penjabaran diatas untuk lembaga pendidikan Pesantren Pangeran Diponegoro telah memenuhi syarat perbaikan dan peningkatan sarana dan prasarana pendidikan berdasarkan asas kebutuhan (Sukmadinata 2010). Ponpes Pangeran Diponegoro berdiri diatas tanah milik yang cukup luas dengan fasilitas yang memadai seperti 
Masjid, Asrama santri, Kantor administrasi, Asrama pengasuh, Dapur, Gedung sekolah, Lapangan untuk olahraga, Koperasi santri, Praktik bengkel, Lab Tata Busana, Perpustakaan, Laboratorium komputer, Laboratorium bahasa, Gudang penyimpnan, Kamar mandi, dan Klinik kesehatan. Gedung Asrama untuk pesatren putri dan putra masing-masing 3 ruangan, gedung sekolah juga tersedia cukup banyak. Untuk SD terdapat 6 jenjang, dari jenjang-jenjang tersebut terdapat 4 kelas, untuk SMP terdapat 3 jenjang, dari masing-masing jenjang tersebut terdapat 3 kelas, dan untuk SMK terdapat 2 jurusan, dari kelas 1 sampai 3 perjurusan ada 6 kelas. Namun komplek gedung Ponpes Pangeran Diponegoro masih dalam kawasan yang terbuka belum ada pembatas atau gerbang antara komplek pesantren, hal ini mempengaruhi proses pengawasan terhadap para santri, meskipun seperti itu, pihak yayasan terus berusaha mengembangkan pembangunan pesantren, terbukti gedung yang bertambah setipa tahunnya, dan hingga saat ini pun, pembangunan fasilitas gedung masih berlangsung.

3) Sistem Evaluasi yang menekankan pada aspek Aplikatif bukan hanya bersifat kognitif atau sebagai jargon yang dihafalkan dengan prinsip-prinsip integraistas, komunitas dan obtektifitas yang adil (Tatang 2015). Dengan adanya fasilitas yang memadai seperti berbagai macam laboratoruim, sistem evaluasi yang diterpakan pada sekolah di pesantren Pangeran Diponegoro juga melibatkan aspek aplikatif yaitu praktikpraktik pelajaran yang didapat (Mega Sari 2018). Untuk sistem evaluasi pondok juga penilaian keseharian yang diterapkan dengan peraturan yang ada juga dilibatkan dalam penilaian, dimana santri tidak dinilai dari kognitifnya saja juga dari sisi afektif dengan penilaian keseharian oleh pengurus Ponpes.

4) Meningkatkan profesionalisme guru dan staf. Selain dalam rangka peningkatan prestasi peserta didik, lembaga juga harus memperhatikan meningkatkan kompetensi dan kemampuan para pengajar,(Nanat Fatah 2007). Salah satu yang di lakukan oleh pesantren Pangeran Diponegoro adalah, menunjang sertivikasi para guru-guru yang terdapat pada sekolah-sekolah yang di dalamnya, mengikuti perlombaan yang diadakan untuk guru, juga memberikan mengikutkan para guru dan staf pelatihan-pelatihan yang menunjang kemampuan kompetensi tersebut.

5) Menjaga hubungan silaturahmi dengan stakeholder pendidikan. Menjanga hubungan dengan masyarakat sekitar merupakan hal yang penting dalam pendirian sebuah lembaga, diharapkan sebuah lembaga yang didirikan juga bermanfaat untuk masyarakat sekitar (Irfan 2012). Ponpes Pangeran Diponegoro didirikan oleh seorang yang sudah tinggal di daerah tersebut jadi, untuk hubungan dengan pihak masyarakat sekitar sangat terbuka, pihak pesantren pun mengagendakan Pengajian Akbar untuk masyarakat sekitar. Sedangkan pada pendidikan sekolah, hubungan silaturahmi dilaksanakan sama seperti pada sekolah lain, setiap semester ada rapat yang para orangtua murid, dan setiap pembangunan dan program dari sekolah selalu melibatkan komite sekolah (Miftahul 2015).

6) Program-program Ponpes Pangeran Diponegoro yang tersosialisasikan kepada stakeholder baik internal maupun eksternal dengan prinsip melayani bukan dilayani tanpa memandang status sosial masyarakat. Lembaga juga harus memiliki program dan selanjutnya menentukan sasaran program program dan mutu yang jelas yang berkomitmen pada subyek atau sasaran.(Miftahul 2015)

Dalam hal ini Ponpes Pangeran Diponegoro merumuskan tujuan dari setiap program mutu dengan memposisikan sekolah di bawah pesantren, sehingga tujuan sekolah akan selaras dengan tujuan pesantren secara umum. Ketercapaian mutu secara agama dan sains menjadi daya tarik dan keuinikan tersendiri bagi sekolah. Sebab pada dasarnya masyarakat juga menginginkan kedua nilai tersebut secara seimbang.

Pesantren Pangeran Diponegoro juga mempunyai lembaga panti yang didirikan sebagai wadah bagi anak yang berasal dari keluarga yang tidak mampu, yang membedakan antara anak panti dan pesantren hanya di bagian administrasi, untuk kegiatan semua sama. Anak yang berkategori dari panti tidak dibebani biaya sedikit pun. Semua biaya telah ditangung oleh lembaga panti. Anggaran yang masuk dari donatur, pihak pesantren akan mengalokasikan anggaran tersebut untuk lembaga panti ini. Lembaga panti iniah yang menunjukkan prinsip melayani bukan dilayani tanpa memandang status dan kedudukan. 
4755 Manajemen Pondok Pesantren dalam Pengembangan Mutu Pendidikan Islam di Pondok Pesantren Pangeran Diponegoro Sleman - Erhat Zakiyatul Aini

DOI: https://doi.org/10.31004/edukatif.v3i6.1543

\section{KESIMPULAN}

Dapat disimpulkan hasil dari penelitian dari pengolahan data yang di dapatkan peneliti di Ponpes Pangeran Diponegoro, Maguwoharjo, Sleman ini, berdasarkan penjabaran teori-teori yang relevan, bahwa Manajemen perencanaan mutu pendidikan yang dijalankan oleh lembaga pendidikan Ponpes Diponegoro dilakukan dengan memenuhi syarat-syarat pendidikan pesantren bermutu yaitu; 1) Ponpes Pangeran Diponegoro menggabungkan kurikulum pendidikan formal bersama kurikulum pendidikan nonformal. Dengan kegiatan kepesantrenan yang dilakukan dengan mondok yang merupakan perpaduan pendidikan umum (DEPDIKNAS) berbasis sekolah yang sesuai dengan tuntutan stakeholder. 2) Ponpes Pangeran Diponegoro selalu memenuhi sarana dan prasarana yang dibutuhkan dibuktikan dengan banyaknya ekstrakurikuler yang juga berprestasi karena pelatihan dan fasilitas yang lengkap berupa ruangan yang memadai dan alat-alat yang diperbaharui dalam pembelajaran yang merupakan perbaikan dan peningkatan sarana dan prasarana pendidikan berdasarkan asas kebutuhan. 3) Sistem penilaian Ponpes Pangeran Diponegoro tidak hanya sebatas mengadakan ujian tulis, maupun ujian lisan, namun juga ujian praktik dan juga penilaian afektif berupa penilaian keseharian dan kedisiplinan santri atau murid dengan membuat peraturan-peraturan kedisiplinan dan menerapkan konsekuensi terhadap pelanggarnya. 4) Memperhatikan kemampuan guru dan pendidikannya dengan mengikutkan sertivikasi juga mengikutkan pelatihan-pelatihan yang menunjang kompetensi guru serta dihimbau guru-guru untuk mengikuti perlombaan. 5) Menjaga hubungan silaturahmi dengan stakeholder pendidikan seperti masyarakat sekitar dan juga para wali murid atau santri. 6) Program-program Ponpes Pangeran Diponegoro yang tersosialisasikan kepada stakeholder baik internal maupun eksternal dengan prinsip melayani bukan dilayani tanpa memandang status sosial masyarakat.

\section{UCAPAN TERIMA KASIH}

Terimakasih saya ucapkan kepada segenap dosen pengajar Magister Manajemen Pendidikan Islam, terutama dosen pembimbing mata kuliah politik dan kebijakan pendidikan Dr. Sabarudin. yang telah membantu dalam mengarahkan artikel ini. Penulis juga sangat berterimakasih kepada keluarga besar Yayasan Pangeran Diponegoro, para pengurus pondok pesantren juga segenap pendidik di SMP dan SMK Pangeran Diponegoro yang telah mengizinkan penulis untuk melakukan pengambilan data.

\section{DAFTAR PUSTAKA}

Ahmad, Zain Sarnoto. 2013. "Urgensi Peningkatan Mutu Pengelolaan Pesantren Dalam Era Global." Jurnal Educare, Researchgate.Net 04 (1): 49-60. Https://Www.Researchgate.Net/Profile/AhmadSarnoto/Publication/339768603_URGENSI_PENINGKATAN_MUTU_PENGELOLAAN_PESANTRE N_DALAM_ERA_GLOBAL/Links/5e8567e492851c2f52744389/URGENSI-PENINGKATAN-MUTUPENGELOLAAN-PESANTREN-DALAM-ERA-GLOBAL.Pdf.

Basyir, Abd A'la. 2007. Pembaharuan Pesantren. Yogyakarta: Lkis.

Dwi Muryadi, Agustanico. 2017. "Model Evaluasi Program Dalam Penelitian Evaluasi." Jurnal Ilmiah Penjas 3 (1-16). Http://Ejournal.Utp.Ac.Id/Index.Php/JIP/Article/View/538.

El-Sha, HS. Matsuki Dan Ishom, Moh. 2006. Intelektualisme Pesantren. Jakarta: Diva Pustaka.

Fatoni, F. 2019. "Implementasi Permendikbud Nomor 19 Tahun 2016 Tentang Program Indonesia Pintar Dalam Meningkatkan Kualitas Pendidikan Masyarakat.” Http://Digilib.Uinsby.Ac.Id/Id/Eprint/34857.

Feiby, Ismail. 2018. "Manajemen Berbasis Sekolah: Solusi Peningkatan Kualitas Pendidikan.” Journal.IainManado.Ac.Id. Http://Journal.Iain-Manado.Ac.Id/Index.Php/JII/Article/View/541.

Hartono, Yudi. 2017. "Pendidikan Nasional Dan Kualitas Manusia Indonesia Dalam Perspektif Sejarah." 
4756 Manajemen Pondok Pesantren dalam Pengembangan Mutu Pendidikan Islam di Pondok Pesantren Pangeran Diponegoro Sleman - Erhat Zakiyatul Aini

DOI: https://doi.org/10.31004/edukatif.v3i6.1543

AGASTYA: JURNAL SEJARAH DAN PEMBELAJARANNYA 7 (2): 84. Https://Doi.Org/10.25273/Ajsp.V7i2.1491.

Irfan, Paturohman. 2012. "Peran Pendidikan Pondok Pesantren Dalam Perbaikan Kondisi Keberagamaan Di Lingkungannya (Studi Deskriptif Pada Pondok Pesantren Dār Al-Taubah.” Jurbal Tarbawi, 1 (1): 65-74. Http://Jurnal.Upi.Edu/File/07_Peran_Pendidikan_Pondok_Pesantren_Dalam_Perbaikan_Kondisi_Keber agamaan_Di_Lingkungannya_-_Irfan.Pdf.

Madjid, Nurcholis. 2010. Bilik-Bilik Pesantren, Sebuah Potret Perjalanan. Jakarta: Paramadina.

Makin, Moh Dan Baharuddin. 2010. Manajemen Pendidikan Islam. Malang: UIN Maliki Press.

Masyhud, M. Sulthan Dan Kusnurdilo. 2003. Manajemen Pondok Pesantren. Jakarta: Diva Pustaka.

Mega Sari, Lia. 2018. "Evaluasi Dalam Pendidikan Islam.” Al-Tadzkiyyah: Jurnal Pendidikan. Ejournal.Radenintan.Ac.Idejournal.Radenintan.Ac.Id $\quad 9 \quad 211-31$. Http://Www.Ejournal.Radenintan.Ac.Id/Index.Php/Tadzkiyyah/Article/View/3624.

Miftahul, Huda. 2015. "Peran Pendidikan Islam Terhadap Perubahan Sosial." Edukasia: Jurnal Penelitian $\begin{array}{ll}\text { Pendidikanjournal.Iainkudus.Ac.Id } & 10 \\ \text { Http://Journal.Iainkudus.Ac.Id/Index.Php/Edukasia/Article/View/790. }\end{array}$

Moleong, Lexi J. 2018. Metodologi Penelitian Kualitatif. Bandung: PT. Remaja Rosdakarya.

Mulyadi, Mohammad. 2011. "Penelitian Kuantitatif Dan Kualitatif Serta Pemikiran Dasar Menggabungkannya." Jurnal Studi Komunikasi Dan Media 15 (1): 127-38. Http://Jurnal.Kominfo.Go.Id/Index.Php/Jskm/Article/View/52.

Nanat Fatah, Natsir. 2007. "Peningkatan Kualitas Guru Dalam Perspektif Pendidikan Islam.” Jurnal Educationoist Ejournal.Sps.Upi.Edu $\quad$ I $\quad$ (1): 20-27. Http://Ejournal.Sps.Upi.Edu/Index.Php/Educationist/Article/View/25.

Pendidikan, Departemen. 2003. "Undang-Undang Nomor 20 Tahun 2003 Tentang Sistem Pendidikan Nasional." Jakarta: $\quad$ Depdiknas $\quad 33 \quad$ (31): Https://Jdih.Bkpm.Go.Id/Jdih/Userfiles/Batang/UU_20_2003.Pdf.

Siswanto. 2015. "Desain Mutu Pendidikan Pesantren.” KARSA: Jurnal Sosial Dan Budaya Keislaman 23 (2): 258-74. Https://Doi.Org/10.19105/Karsa.V2312.726.

Sukmadinata. 2010. Prinsip-Prinsip Pengembangan Kurikulum. Jakarta: Paramadina.

Suwadji. 2014. "Manajemen Peningkatan Mutu Berbasis Pondok Pesantren.” EDUKASI: Jurnal Pendidikan Islam. Staim-Tulungagung.Ac.Id.

Tulungagung.Ac.Id/Ejournal/Index.Php/EDUKASI/Article/View/103.

Http://Staim-

Syaiful, Anwar. 2016. "Peran Pendidikan Agama Islam Dalam Membentuk Karakter Bangsa.” Al-Tadzkiyyah: Jurnal Pendidikan. $\quad$ Ejournal.Radenintan.Ac.Id $\quad 7:$ 157-69. Http://Ejournal.Radenintan.Ac.Id/Index.Php/Tadzkiyyah/Article/View/1500.

Tatang. 2015. Manajemen Pendidikan Berbasis Sekolah. Bandung: Pustaka Setia. 